УДК 373.2.015.311:796]:373.29

DOI https://doi.org/10.32782/apv/2021.2.6

\title{
Іванна ХЕВРОНА
}

магістрант спеціальності 012 Дочкільна освіта, Волинський національний університет імені Лесі Українки, просп. Волі, 13, м. Луцььк, Волинська область, Україна, 43025

\section{Володимир АНТОНЮК}

кандидат педагогічних наук, доцент кафедри загальної педагогіки та дошкільної освіти, Волинський національний університет імені Лесі Украӥнки, просп. Волі, 13, м. Луцьк, Волинська область, Україна, 43025

ORCID: 0000-0002-6080-8728

Бібліографічний опис статті: Хеврона, І., Антонюк, В. (2021). Формування фізичної готовності дітей старшого дошкільного віку до навчання в школі. Acta Paedagogica Volynienses, 2, 36-42, doi: https://doi.org/10.32782/apv/2021.2.6

\section{ФОРМУВАННЯ ФІЗИЧНОЇ ГОТОВНОСТІ ДІТЕЙ СТАРШОГО ДОШКІЛЬНОГО ВІКУ ДО НАВЧАННЯ В ШКОЛІ}

Необхідність істотних зрушень у дошкільній освіті актуалізується вступом до першого класу школи шестирічних учнів, а отже, забезпечення готовності дитини до наступних змін у ї̈ соціальній позиції має стати одним із провідних напрямів діяльності ЗДО.

На ицьому етапі перед педагогами дошкільної ланки закономірно постає проблема наступності. Зауважимо: фізичне виховання дошкільнят здійснюється задля його оздоровчої та розвивальної функиій, завдяки чому діти набувають фізичної готовності до навчання у школі.

Фізична готовність як одна з найголовніших складових загальної готовності до шкільного навчання визначається станом здоров'я майбутнього першокласника, рівнем його рухових умінь, розвитком фізичних якостей, сформованістю навичок самообслуговування та культурно-гігієнічних навичок, правильної постави, самостійністю і творчістю в руховій сфері.

Ключові слова: діти старшого дошкільного віку, готовність до навчання, фізична готовність.

\section{Ivanna HEVRONA}

Master of Specialty 012 Preschool Education Lesya Ukrainka Volyn National University, 13 Voli Ave., Lutsk, Ukraine, 43025

\section{Volodymyr ANTONIUK}

PhD in Pedagogy, Senior Lecturer at the Department of General Pedagogy and Preschool Education, Lesya Ukrainka Volyn National University, 13 Voli ave., Lutsk, Volyn region, Ukraine, 43025

ORCID: 0000-0002-6080-8728

To cite this article: Hevrona I. \& Antoniuk V. (2021). Formuvannia fizychnoi hotovnosti ditei starshoho doshkilnoho viku do navchannia $\mathrm{v}$ shkoli [Formation of physical readiness of children of senior preschool age to school]. Acta Paedagogica Volynienses, 2, 36-42, doi: https://doi.org/10.32782/apv/2021.2.6

\section{FORMATION OF PHYSICAL READINESS OF CHILDREN OF SENIOR PRESCHOOL AGE TO SCHOOL}

The need for significant changes in preschool education is actualized by the entry of six-year-old students into the first grade of school, and therefore, ensuring the child's readiness for further changes in his social position should become one of the leading activities of preschool education.

At this stage, preschool teachers naturally face the problem of continuity. Note: physical education of preschool children is carried out for its health and developmental functions, thanks to which children acquire physical readiness for school.

Physical fitness as one of the most important components of general readiness for school is determined by the state of health of the future first-grader, the level of his motor skills, development of physical qualities, self-care skills and cultural and hygienic skills, proper posture, independence and creativity in the motor field.

Key words: children of senior preschool age, readiness to study, physical readiness. 
Постановка проблеми в загальному вигляді та її зв'язок з важливими науковими та практичними завданнями.

Одним із важливих показників життєдіяльності дитини є стан іiі здоров'я - міцної основи успішного сьогоднішнього й завтрашнього життя. Тож у питанні фізичної готовності до школи маємо зважати не лише на формування рухового досвіду дітей, розвиток їхніх фізичних якостей, а передусім на ефективність зміцнення здоров'я, забезпечення високого рівня працездатності, витривалості.

Аналіз сучасної практики фізичного виховання дітей старшого дошкільного віку в закладах дошкільної освіти свідчить про існування низки протиріч: між зростанням кількості дітей, які систематично хворіють на респіраторні інфекції, мають хронічні захворювання і відсутністю оздоровчої спрямованості процесу їхнього фізичного виховання; між високими вимогами до фізичного стану та фізичного розвитку дітей, які опановують програму початкової освіти й недостатнім фізичним розвитком і станом фізичного здоров'я дітей старшого дошкільного віку, які приходять до першого класу школи.

Аналіз останніх досліджень і публікацій 3 проблеми. Сучасний етап вивчення проблеми привертає увагу вчених, психологів і педагогів-практиків. Питання вікової та педагогічної психології розглядають Л. Волинська, С. Огороднійчук, О. Скрипченко, психологію освіти Л. Петровський, Н. Гуткіна, I. Дубровина. Різноманітні аспекти психологічної адаптації вивчають М. Зеленова, В. Цилев, загальні питання соціалізації дитини аналізує М. Лукашевич, Г. Люблінська.

Фізіологічні особливості дошкільнят, зміст, форми і завдання фізичного виховання в умовах дошкільного навчального закладу вивчають Г. Бєлєнька, Е. Вільчковський, Г. Ляшенко, М. Стельмахович, оцінювання фізичної підготовленості розглядає О. Дубогай.

Формулювання мети статті та завдань. Мета наукової розвідки -обгрунтувати принципи та педагогічні умови формування фізичної готовності дітей старшого дошкільного віку до навчання в школі.

Виклад основного матеріалу. Організація навчання дітей на дошкільному та початковому освітніх етапах потребує взаємної зорі- єнтованості освітньо-педагогічної діяльності вихователів та вчителів, погоджених спільних дій у цілепокладанні, проектуванні процесу навчання дітей різного віку. Початкова ланка, спираючись на досягнення дошкільного віку, має підхопити, зміцнити, розвинути набуте до школи.

Характеризуючи наступність як “створення певних перехідних умов, за яких давні, усталені звички без істотного їх ламання могли б дати хід розвитку нових звичок", дослідниця О. Усова завдання дошкілля вбачає в тому, щоб “забезпечити такий рівень всебічного розвитку дітей, спираючись на який, учитель зможе успішно їх навчати й виховувати". По цьому актуалізує завдання учителів початкової школи в контексті неперервності освіти: “Поводитися 3 набутим в дошкільний період, як з цінним матеріалом, шукати і знаходити в ньому потрібне для всебічного розвитку дітей” $[6$, с. 35$]$.

Термін “фізичний розвиток” використовують у різних тлумаченнях: 1) як процес зміни форм і функцій (морфо-функціональних властивостей) організму людини протягом іiі індивідуального життя; 2) як сукупність ознак, що характеризують зовнішні показники “фізичного стану" організму на тому чи тому етапі його фізичного розвитку (ріст, вага, окружності тіла, спірометрія, динамометрія тощо).

Як зазначають учені В. Іващенко та О. Безкопильний $[5$, с. 32], про рівень фізичного розвитку судять 3 огляду на ті показники, за допомогою яких оцінюють опорно-руховий апарат, нервово-м'язову, дихальну, серцево-судинну системи. Отже, критеріями фізичного розвитку зазвичай слугують такі параметри, як зріст, вага тіла, окремі кількісні визначники форми хребта і ніг, об'єм грудної клітки, індекс довжини рук і ніг, певні кількісні показники рухливості в суглобах, життєва ємність легень, частота серцевих скорочень в стані спокою, артеріальний тиск, сила м'язів кисті та станова сила [5, с. 32]. Ознаки фізичного розвитку умовно виокремлюють у три групи: соматометричні, соматоскопічні і фізіометричні.

Фізична готовність - це стан здоров'я, певний рівень морфорфункціональної зрілості організму дитини, необхідний рівень розвитку рухових умінь та навичок, тонких моторних координацій, фізична і розумова працездатність [4, с. 15]. 
Іншими словами, фізична готовність як один 3 найголовніших складників загальної готовності до шкільного навчання визначається:

- станом здоров'я майбутнього першокласника;

- рівнем його рухових умінь, розвитку фізичних якостей;

- сформованістю гігієнічних навичок, правильної постави;

- самостійністю і творчістю в руховій сфері;

- належним станом соматичного здоров'я і фізичної підготовки.

Фізична готовність як одна 3 найголовніших складових загальної готовності дітей до шкільного навчання визначається: станом здоров'я майбутнього першокласника; рівнем його рухових умінь, розвитку фізичних якостей; сформованістю гігієнічних навичок, правильної постави; самостійністю і творчістю в руховій сфері; належним станом соматичного здоров'я й фізичної підготовленості.

Критеріями фізичної готовності було обрано фізичну, рухову, оздоровчо-валеологічну компетентність. Визначимо їх.

Структура фізичної готовності дітей старшого дошкільного віку до навчання у школі, яка подана у таблиці 1.1 .

Учені зазначають, що засадничими моментами у фізичній підготовці дітей є вдало підібрані фізичні навантаження. Тренувальні навантаження мають бути ані надмірними, ані недостатнього обсягу, тобто дозування мають бути оптимальними. 3 іншого боку, їх слід добирати, зважаючи на вік, стан здоров'я, стать, рівень загальної фізичної підготовленості дітей. Лише в такому випадку фізична підготовка дітей приноситиме користь.

Викладене вище дозволяє дійти висновку про те, що, по-перше, величина фізич- них навантажень - важливий (засадничий) складник тренувального процесу; по-друге, їх дозування має бути оптимальним; по-третє, величина фізичних навантажень може бути вибірковою (спрямованою на виховання певної фізичної здібності) і загальною (передбачає сумарний вплив всього вибіркового фізичного навантаження). Між тим, учені зауважують, що тренувальні (фізичні) навантаження впливають не тільки на підвищення фізичної та розумової працездатності дітей, а й на профілактику захворювань. Дослідниця К. Козлова, крім іншого, рекомендує при дозуванні фізичних навантажень зважати на такі чинники: засоби та нормування величини навантажень в аеробному режимі; збільшення кількості вправ 3 дихальної гімнастики; використання вправ на гнучкість та розслаблення; неприпустимість виконання вправ на тлі втоми; інтенсивність навантажень, яка не повинна перевищувати 75-85\% від максимальної. О. Бельський відповідність фізичних навантажень функціональним можливостям організму кваліфікує як основну умову підвищення рівня фізичної підготовленості дітей, зазначаючи, що механізм дії тренувальних навантажень на дитячий організм варто оцінювати, зважаючи насамперед на показники стомлення, дані працездатності (за показниками частоти серцевих скорочень [1].

Обов'язковим елементом тренувального процесу є відпочинок (паузи) між виконанням фізичних вправ. Власне, методичною умовою організації занять 3 фізичного виховання $€$ почергове проведення тренувального навантаження та активного відпочинку. Фахівці в галузі фізичного виховання зазначають, що для розвитку певних фізичних здібностей дошкільників слід зважати на такий фактор, як час, котрий

Таблиця 1.1

\section{Структура фізичної готовності дітей до навчання у школі}

\begin{tabular}{|l|l|}
\hline \multicolumn{1}{|c|}{ Критерії } & \multicolumn{1}{c|}{ Показники } \\
\hline Фізична компетентність & $\begin{array}{l}\text { - обізнаність дітей з будовою тіла і доглядом за ним; - наявність уявлення про своє } \\
\text { фізичне “я” (антропометричні дані), уміння управляти й контролювати фізичний } \\
\text { стан свого організму вонкретній ситуації }\end{array}$ \\
\hline Рухова компетентність & $\begin{array}{l}\text { - наявність умінь і навичок з основних рухів (ходьба, біг, стрибки, метання, лазіння); } \\
\text { - розвиток моторики; } \\
\text { - вміння самостійно виконувати загальнорозвивальні вправи, ранкову гімнастику; } \\
\text { - ініціативність у проведенні рухливих ігор }\end{array}$ \\
\hline $\begin{array}{l}\text { Оздоровчо- валеологічна } \\
\text { компетентність }\end{array}$ & $\begin{array}{l}\text { - обізнаність із впливом основних природних чинників на стан здоров’я (сонце, } \\
\text { повітря, вода, грунт); } \\
\text { - наявність елементарних умінь і навичок загартування організму; } \\
\text { - обізнаність із показниками свого здоров'я (самопочуття, апетит, настрій) } \\
\text { та нездоров'я, назвами найпоширеніших дитячих захворювань }\end{array}$ \\
\hline
\end{tabular}


відводиться для відпочинку і котрий визначається за показниками частоти серцевих скорочень. Врахування цього чинника $є$ важливим для відновлення діяльності дитячого організму і його систем.

Щодо фізичної підготовки дітей дошкільного віку, то тут застосовують оздоровчі тренування (процес адаптації організму до фізичних навантажень задля зміцнення здоров'я, досягнення фізичної досконалості, формування здорового способу життя, розвитку рухової активності, фізичного і психічного потенціалу дитини). Слід зауважити, що в сучасній педагогічній науці чимало вчених обстоюють ідею щодо використання оздоровчих технологій (тренувань) у процесі фізичного виховання дошкільників, обгрунтовуючи іiі тим, що традиційно усталена методика проведення занять 3 фізкультури у дошкільному навчальному закладі сповна не реалізує оздоровчі завдання, позаяк насамперед забезпечує засвоєння рухових навичок, формування умінь, відтак чинна методика проведення занять 3 фізичної культури не передбачає інтенсивність адаптації дитини до тренувального навантаження та за своїм фізичним навантаженням недостатня для досягнення оздоровчого ефекту та тренованості організму дошкільників.

3 метою оздоровлення дошкільників на заняттях із фізичної культури варто застосовувати вправи, що всебічно впливають на системи дитячого організму, мають виразний тренувальний характер. Як слушно зауважують учені (Н. Амосов, В. Бальсевич, В. Новохатько, Е. Панкратьєв), тренувальні навантаження, які не спричинюють напруги фізіологічних функцій, не поліпшують м'язової діяльності, відтак не забезпечують реалізацію оздоровчих завдань. Власне, колове тренування, на думку науковців, $\epsilon$ найкращою формою організації фізичної підготовки, оскільки спрямовує на комплексний розвиток фізичних якостей у дітей [2; с. 281].

Основним засобом фізичного виховання $\epsilon$ фізичні вправи, сутність яких полягає у сукупності якостей і процесів (фізіологічних, психічних та ін.), що визначають їх вплив на дієздатність організму, на формування вмінь і навичок, на фізичний розвиток людини загалом [2; с.53]. Фізичні вправи вчені визначають як спеціально дібрані, керовані педагогами рухи і складні види рухової діяльності. Фізичні вправи роз- вивають у дітей не тільки рухову активність, підвищують діяльність усіх систем організму, а й спричинюють розвиток уваги, мислення, волі, емоцій, тощо, поліпшують загальнофізичну підготовку дітей, зміцнюють здоров'я.

До важливих принципів побудови системи занять 3 фізичної культури у дошкільному навчальному закладі відносимо принцип диференціації, який забезпечує індивідуальний підхід у процесі фізичного виховання дітей, що передбачає глибоке вивчення стану здоров'я, фізичного розвитку, особливостей психіки, рівня розвитку рухових якостей дитини тощо. Цей принцип допомагає педагогові “знайти правильний шлях для оптимального впливу на фізичний розвиток та стан здоров'я дитини", особливо при додаткових фізичних навантаженнях. Погоджуємося з думкою вчених про те, що сьогодні диференціація дітей за рівнем фізичної підготовленості 3 урахуванням фізіологічних можливостей дитячого організму, стану здоров'я і психічних якостей дітей, а також функціональних показників має стати провідним принципом побудови системи занять 3 фізичної культури у дошкільному навчальному закладі.

У процесі фізичного виховання у дошкільників не тільки зміцнюється здоров'я, поліпшується фізичний розвиток, а й розвиваються розумові здібності, формуються позитивні моральні й вольові якості, естетичні смаки. Іншими словами, йдеться про принцип гармонійного розвитку особистості, що грунтується на ідеї зв'язку фізичних і духовних сил людини (О. Запорожець, I. Павлов, С. Русова, В. Сухомлинський, ін).

Одне із завдань фізичного виховання дошкільників - забезпечення зміцнення здоров'я. Власне, цю мету реалізує принцип оздоровчої спрямованості, який “живить” зміст та реалізується через засоби фізичного виховання дітей дошкільного віку, зокрема шляхом щоденних занять 3 фізичної культури, спеціальних фізичних вправ, гімнастики, рухливих ігор, а також засобами, покликаними активно впливати на дитячий організм, - загартовувальними процедурами, харчуванням, режимом дня, гігієнічними процедурами тощо. Крім того, оздоровчий характер занять передбачає насамперед добір відповідного науково-методичного забезпечення; посилення фізичних навантажень (обсягу та інтенсивності) відповідно до вікових та інди- 
відуальних особливостей дітей, стану здоров'я тощо; правильне поєднання фізичних навантажень і відпочинку; проведення профілактики щодо запобігання захворювань та травматизму в дітей. Відтак регулювання працездатності дошкільників, чергування фізичних навантажень і відпочинку уможливлюють забезпечення структурно-функціональної роботи мозку, сприяють активізації процесу мислення, морфофізіологічному розвитку організму; усе це створює підгрунтя для зміцнення, оздоровлення дітей, збільшення резервів дитячого організму.

Відомо, що правильно підібрані фізичні вправи й рухливі ігри сприяють оздоровленню дошкільників, оскільки формують не тільки життєво необхідні навички рухової діяльності, а й ефективно впливають на розвиток м'язової системи: скажімо, виконання статичних і динамічних вправ спричинює чергування напруження $з$ розслабленням м'язів. Цю властивість м'язової системи дитини ми враховували, плануючи заняття. Отож у дошкільників формували вміння зняти напруження, виконувати рухи невимушено, розслабляти м'язи. Між тим, як зазначають фахівці, оздоровчий ефект наступає тільки тоді, коли оздоровчі види занять виконуються з достатньою інтенсивністю.

У працях Е. Вільчковського, Н. Денисенко, О. Дубогай, П. Лесгафта, Т. Осикіної, С. Тимофеєвої актуалізовано принцип єдності дошкільного навчального закладу і сім’їу фізичному вихованні дітей. На основі ідей М. Амосова, Л. Виготського про взаємозв'язок рухової активності й інтелектуального розвитку дитини доходимо висновку про винятково важливу роль сім'ї у підготовці дитини до шкільного навчання. Звідси окреслюється одне із завдань батьків - розвиток рухових якостей (сили, швидкості, витривалості, спритності, гнучкості) у дітей, підвищення функціонального стану всіх систем організму. 3 метою реалізації принципу єдності дошкільного навчального закладу і сім'ї нами розроблено методику роботи з батьками, яку впроваджували в процесі експериментального дослідження.

Цілком поділяємо наукові ідеї Л. Глазіна про те, що фізична підготовка дошкільників до навчання в школі може відбуватися більш ефективно, якщо задіяти нетрадиційні принципи:

- принцип синкретичності, що відображає наявність загальних витоків єдності у виборі засобів і методів впливу на дитину;
- принцип фасцинації відображає позитивну соціально-психологічну атмосферу на занятті;

- принцип творчої співпраці, результатом чого є самостійне створення дитиною нових рухів на основі рухового досвіду і мотиву до діяльності [3].

Сутність фізичної підготовки дітей старшого дошкільного віку полягає у реалізації трьох груп завдань: оздоровчих; освітніх (формування рухових навичок і умінь, фізичних якостей); виховних (виховання культурно-гігієнічних навичок, основ здорового способу життя). У процесі фізичного виховання важливим $є$ залучення дошкільників до самостійної рухової діяльності, свідомого ставлення до власного здоров'я. Отже, завдання вихователя - керувати комплексом організаційних форм фізичної культури, самостійним руховим режимом дітей, створювати належний емоційний мікроклімат 3 метою заохочення їх до занять фізичною культурою, добирати засоби комплексного впливу на організм дитини.

Відповідно до методологічних, теоретичних засад i принципів організації побудови експериментального дослідження було визначено педагогічні умови, що передбачають ефективне формування фізичної готовності дітей до навчання у школі. 3-поміж них: врахування стану фізичного здоров'я кожної дитини; наявність позитивних стимулів до систематичних занять фізичними вправами; залучення батьків до спільної роботи 3 фізичної підготовки дітей до школи.

Наявність значної кількості дітей, які часто хворіють на респіраторні інфекції, мають хронічні захворювання, недостатній фізичний розвиток та низьку фізичну підготовленість, свідчить про необхідність поліпшити роботу з фізичного виховання у дошкільних навчальних закладах. Головне завдання дорослих полягає в тому, щоб зміцнити здоров'я майбутніх громадян України. Ще в дошкільному віці дитина засвоює певні знання з гігієни, практичні вміння та навички, які сприяють збереженню, зміцненню та формуванню її здоров'я. Оцінка стану здоров'я дітей з урахуванням функціональних потреб дозволяє правильно визначити можливості організму дитини і більш чітко дозувати фізичні навантаження під час виконання вправ. Відтак, перша педагогічна умова - врахування стану фізичного здоров'я кожної дитини. 
Наступною умовою ми обрали - наявність позитивних стимулів до систематичних занять фізичними вправами. Всю рухову діяльність малюків, усі заходи спрямовані на зміцнення їхнього здоров'я, треба проводити тільки на позитивному емоційному тлі. Успіх завжди підсилює властиве дитині прагнення до діяльності, підвищує іiі активність у навчальному процесі, наполегливість під час виконання пропонованих вихователем завдань, забезпечує підвищену працездатність і більш високу успішність. Під час ігор створюється нестресогенний психологічний мікроклімат, який сприяє саморегуляції дитини. Це такий психічний стан, коли імпульсивність, агресивність, тривожність перебувають у дитини в межах норми. Урівноважена центральна нервова система подає позитивні імпульси до внутрішніх органів та систем, які безпосередньо виконують біологічні функції.

Наступна педагогічна умова, що сприяє ефективному формуванню фізичної готовності дітей до навчання у школі, у контексті нашого дослідження - залучення батьків до спільної роботи 3 фізичної підготовки дітей до школи.

Одним із основних напрямів діяльності $\epsilon$ спрямованість на співпрацю 3 батьками. У ст. 59 Закону України “Про освіту” зазначено, що батьки зобов'язані піклуватися про здоров'я своїх дітей, їх фізичний і духовний розвиток, ведення ними здорового способу життя.

Формування фізичної готовності дітей нами здійснюється за трьома послідовними етапами:

- розвивально-тренувальний;

- репродуктивно-діяльнісний;

- діяльнісно-творчий.

Робота спрямована за основними показниками фізичної готовності дітей до навчання у школі:

- обізнаність дітей з будовою тіла та доглядом за ним; наявність уявлення про своє фізичне “Я” (антропометричні дані), уміння управляти й контролювати фізичний стан свого організму в конкретній ситуації;

- наявність умінь і навичок з основних рухів (ходьба, біг, стрибки, метання, лазіння);

- розвиток моторики; вміння самостійно виконувати загальнорозвивальні вправи, ранкову гімнастику;
- ініціативність у проведенні рухливих ігор;

- обізнаність із впливом основних природних чинників на стан здоров'я (сонце, повітря, вода, грунт);

- наявність елементарних умінь і навичок загартування організму; обізнаність із показниками свого здоров'я (самопочуття, апетит, настрій) та нездоров'я, назвами найпоширеніших дитячих захворювань.

Змістовим аспектом роботи виступають заняття з фізичної культури, валеології, ранкова гімнастика, фізкультурно-оздоровчі заходи, валеохвилинки, емоційно-насичені ігрові технології: рухливі ігри, ігри змагального характеру, імітаційні вправи, рухові шаради, фізкультурні хвилинки, паузи, мімічні вправи, самостійні заняття фізичними вправами.

Такий комплексний підхід до формування фізичної готовності дітей до навчання у школі сприяе позитивному ставленню до занять фізичною культурою, у дітей зростає потреба у систематичних заняттях фізичними вправами.

Висновки та перспективи подальших досліджень.

Фізична готовність до шкільного навчання визначається: станом здоров'я майбутнього першокласника; рівнем його рухових умінь, розвитку фізичних якостей; сформованістю гігієнічних навичок, правильної постави; самостійністю і творчістю в руховій сфері, фізичною підготовленістю. Критеріями сформованості фізичної готовності старших дошкільників до шкільного навчання $\epsilon$ фізична, рухова та оздоровчо-валеологічна компетентності. Важливими принципами побудови системи занять 3 фізичної культури у ЗДО є принцип диференціації, принцип гармонійного розвитку особистості, принцип оздоровчої спрямованості, принцип єдності дошкільного навчального закладу і сім'ї. Педагогічними умовами, що передбачають ефективне формування фізичної готовності дітей до навчання у школі $є$ врахування стану фізичного здоров'я кожної дитини; наявність позитивних стимулів до систематичних занять фізичними вправами; залучення батьків до спільної роботи з фізичної підготовки дітей до школи.

Подальшого вивчення потребують зміст і методика фізичної підготовки до школи дітей, які не відвідують закладів дошкільної освіти. 


\section{ЛІТЕРАТУРА:}

1. Бельський О.М. Параметри фізичних навантажень під час розвитку рухових якостей у школярів 10-12 років / Матеріали 2-ї всеукраїнської науково-практичної конференції “Концепція підготовки спеціалістів фізичної культури в Україні”, Луцьк : Вежа. 2006. С. 355-359.

2. Вільчковський Е.С. Курок О.І. Теорія і методика фізичного виховання дітей дошкільного віку: Навчальний посібник / В.К. 2-ге вид., перероб. та доп., Суми: ВТД «Університетська книга», 2008. 428 с.

3. Волков Л.В. Теория и методика детского и юношеского спорта, Київ : Олимпийская литература, 2012., $294 \mathrm{c}$.

4. Герцик М.С. Вступ до спеціальностей галузі «Фізичне виховання і спорт» : підручник / М.С. Герцик, О.М. Вацеба., Харків : ОВС, 2009., 240 с.

5. Іващенко В.Г. Теорія і методика фізичного виховання : підручник, Черкаси : Видавництво ЦНТЕІ, 2012., Ч. 2., 2006., $467 \mathrm{c}$.

6. Усова А.П. Дидактические основы связи и преемственности в работе между детским садом и школой, /Подготовка детей в детском саду к школе / под ред. А.П. Усовой. Москва : Изд-во АПН РСФСР, 2005.

\section{REFERENCES}

1. Belskyi O.M. Parametry fizychnykh navantazhen pid chas rozvytku rukhovykh yakostei u shkoliariv 10-12 rokiv/ Materialy 2-yi vseukrainskoi naukovo-praktychnoi konferentsii "Kontseptsiia pidhotovky spetsialistiv fizychnoi kultury v Ukraini”, Lutsk: Vezha. 2006. S. 355-359. [in Ukrainian].

2. Vilchkovskyi E.S. Kurok O.I. Teoriia i metodyka fizychnoho vykhovannia ditei doshkilnoho viku: Navchalnyi posibnyk / V.K. 2-he vyd., pererob. ta dop., Sumy: VTD «Universytetska knyha», 2008. 428 s. [in Ukrainian].

3. Volkov L.V. Teoryia y metodyka detskoho y yunosheskoho sporta, Kyiv: Olympyiskaia lyteratura, 2012., 294 s. [in Ukrainian].

4. Hertsyk M.S. Vstup do spetsialnostei haluzi "Fizychne vykhovannia i sport" : pidruchnyk / M.S. Hertsyk, O.M. Vatseba., Kharkiv: OVS, 2009., 240 s. [in Ukrainian].

5. Ivashchenko V.H. Teoriia i metodyka fizychnoho vykhovannia : pidruchnyk, Cherkasy : Vydavnytstvo TsNTEI, 2012., Ch. 2., 2006., 467 s. [in Ukrainian].

6. Usova A.P. Dydaktycheskye osnovy sviazy y preemstvennosty v rabote mezhdu detskym sadom y shkoloi / Podhotovka detei v detskom sadu k shkole / pod red. A.P. Usovoi., Moscow : Yzd-vo APN RSFSR, 2005 [in Russian]. 